\title{
Management Challenges in Uncertain Environment
}

\author{
B. A. Anuradha \\ Al-Ameen Institute of Management Studies, Affiliated to Bangalore University, India
}

Copyright $(2016$ by authors, all rights reserved. Authors agree that this article remains permanently open access under the terms of the Creative Commons Attribution License 4.0 International License

\begin{abstract}
The final phase of last century has witnessed dramatic and drastic changes in the spheres of business around the globe. The advancement in science and technology has conquered the space, time \& distance, thus transforming the world into a global village. Change is the operating lever of the $21^{\text {st }}$ Century business. The present business is driven by technology and business is knowledge based. The twin forces of globalization \& technology revolution has orchestrated a whole new wave of changes across economies, societies thereby radically impacting the way we lead our businesses. Excellent businesses across the world have a Heart Beat! Gone are the days where people were treated as liabilities and were put under stringent work rules. Likewise management is no longer about control, command, hierarchy, title or status but is everything about making a difference, creating positive change, encouraging, enabling and empowering every employee. Thus organizations are embracing the emerging leadership practices such as Shadow Resourcing, or Succession Planning, Professional Hibernation, and Reverse Mentoring.
\end{abstract}

Keywords Employee Engagement, Leadership Crisis, Shadow Resourcing, Professional Hibernation, Reverse Mentoring

\section{Introduction}

The final phase of last century has witnessed dramatic and drastic changes in the spheres of business around the globe. The advancement in science and technology has conquered the space, time $\&$ distance, thus transforming the world into a global village. Change is the operating lever of the $21^{\text {st }}$ Century business. The present business is driven by technology and business is knowledge based. The twin forces of globalization \& technology revolution has orchestrated a whole new wave of changes across economies, societies thereby radically impacting the way we lead our businesses. All great companies have some kind of success formula emulating from a unique set of strategic frames, resources, processes, relationships \& values. But, when the formula hardens, companies lose a vital ingredient for continued success.

Managers tend to adopt impersonal if not passive attitudes towards goals. Managerial goals arise out of necessities rather than desires and hence are deeply embedded in their organizations history \& culture. The example of Polaroid camera where there elapses a shot interval between snapping the picture and gaining pleasure by seeing the shot suggests as to how business leaders think about goals. Business leaders are active instead of reactive, shaping ideas instead of responding to them. They should adopt a personal \& active attitude towards business goals. The influence a leader exerts in altering moods, invoking images \& expectations and in establishing specific desires and objectives determines the direction the business takes! The Result-Influence changes the way people think about what is desirable, possible and necessary.

Business leaders take a personal interest in the long-term development of their employees using their tack and social skills to encourage employees to achieve their best. It isn't about being nice or understanding, but it is all about tapping into individual motivations in the interest of furthering business goals.

It should be noted that management works in the system, while business leadership works on the system. Authentic business leaders are characterized by influence, integrity, impact, insight, initiative, know the purpose of their leadership and have self-discipline.

Business leaders should take the opportunity as it comes, bearing in mind the bitter truth of the luck, giving you an opportunity but does not give you the result!

It takes optimism to dream about a better tomorrow, vision to chart a course to get there, tenacity to confront challenges and overcome obstacles, administrative acumen to desire \& implement projects \& programmes that catapult people from deprivation $\&$ despair to hope \& prosperity.

\section{Materials and Methods}

The area of study is Bangalore and includes established, government, private and multinational companies across 3 sectors viz., manufacturing, services \& IT 
The research study utilized survey, analytical \& empirical methodology.

Primary data was collected with the help of a well-structured questionnaire and personal interviewing of the respondents. The study has considered 30 companies as sample units i.e., 10 each from manufacturing, services \& IT sector in the field of automobiles, electronics, telecommunications, banking, insurance and IT.

The sample firms were picked up using judgmental \& purposive method of sampling wherein the select organization had a minimum turnover of Rs. 25 Crores p.a. and that the minimum workforce strength of 200 .

In each of the sample firms so selected, 10 managerial executives were administered the questionnaire on a random basis. Thus altogether from the 30 sample firms, 300 managerial executives constitute the sample size.

The data gathered through questionnaire and personal interviews have been edited, classified and tabulated for the purpose of statistical analysis viz., Factor Analysis \& ANOVA.

It is absolutely essential to know the evolution of the workplace to understand as to why and how things are being done today. While change is and always will be a part of life, changing for the sake of changing is and always be ineffective and potentially disastrous for a firm. Understanding the threat of keeping outdated ways of working and mindsets in the workplace is important but too much change or the undesirable change can be just as harmful or may even backfire.

HR practices may not be uniform for all types of industries. In manufacturing and engineering industry, the HR practices will slant towards attracting and retaining engineers and technicians but in service industries it may slant towards public relations experts and in information technology towards knowledge workers. HR experts are of the opinion that though the best practices in HRM cannot be uniformly applied to all the organizations, they have a kind of uniform applicability in some functional areas where psychological factors play an important role such as system of training, inculcation of team spirit and creating an atmosphere of camaraderie within the organization, employee career advancement policy, system of healthy and transparent communication, policy of recognizing and rewarding merit.

This study has been undertaken to throw light on the extent or degree of changes in leadership practices that have taken place in the workplace scenario.

Table source : The data is collected from respondents.

\section{Results}

Table 4 and Figure 1reveal that the mean scores for services sector is the highest when compared to other two sectors. IT sector ranks second, with scores of manufacturing sector being the least, with respect to all the five factors of leadership viz., value and belief system of the leaders, career guidance \& growth opportunities, leader's sensitivity to competitors HR practices, performance recognition \& rewards and corporate governance.

The difference among the sectors with regard to the factors were analyzed and tested for significance through one way ANOVA. The results are presented in Table 5.

Table 5. Annova Table for Leadership Factors

\begin{tabular}{|c|c|c|c|c|c|c|c|}
\hline Valuond boliof & $\begin{array}{l}\text { Source of } \\
\text { Variation }\end{array}$ & $\begin{array}{l}\text { Sumof } \\
\text { Squares }\end{array}$ & $\begin{array}{l}\text { Degree of } \\
\text { Freedom }\end{array}$ & $\begin{array}{l}\text { Mean } \\
\text { Square }\end{array}$ & Fcal & Sig. & Remarks \\
\hline \multirow{2}{*}{$\begin{array}{c}\text { Value and belief } \\
\text { system of the } \\
\text { leaders }\end{array}$} & $\begin{array}{l}\text { Between Groups } \\
\text { Within Groups }\end{array}$ & $\frac{.188}{98.766}$ & $\begin{array}{c}2 \\
297\end{array}$ & $\begin{array}{l}.094 \\
333\end{array}$ & & & \\
\hline & Total & 98.955 & 299 & & & & \\
\hline \multirow{3}{*}{$\begin{array}{c}\text { Career guidance } \\
\text { \& growth } \\
\text { opportunities }\end{array}$} & Between Groups & 5.408 & 2 & 2.704 & 5.355 & .005 & ${ }^{*} \mathrm{~S}$ \\
\hline & Within Groups & 149.974 & 297 & .505 & & & \\
\hline & Total & 155.383 & 299 & & & & \\
\hline \multirow{2}{*}{$\begin{array}{c}\text { Well Defined Pay } \\
\text { for Performance } \\
\text { Systems }\end{array}$} & $\begin{array}{l}\text { Between Groups } \\
\text { Within Groups }\end{array}$ & $\begin{array}{c}3.455 \\
60.809 \\
\end{array}$ & $\begin{array}{c}2 \\
297\end{array}$ & $\begin{array}{r}1.727 \\
.205 \\
\end{array}$ & 8.437 & .000 & ${ }^{*} \mathrm{~S}$ \\
\hline & Total & 64.264 & 299 & & & & \\
\hline \multirow{2}{*}{$\begin{array}{l}\text { Performance } \\
\text { recognition \& } \\
\text { rewards }\end{array}$} & Between Groups & 10.220 & 2 & 5.110 & 8.978 & .000 & ${ }^{*} \mathrm{~S}$ \\
\hline & $\begin{array}{c}\text { Within Groups } \\
\text { Total }\end{array}$ & $\begin{array}{l}169.041 \\
\mathbf{1 7 9 . 2 6 1}\end{array}$ & $\begin{array}{l}297 \\
299\end{array}$ & .569 & & & \\
\hline \multirow[t]{2}{*}{$\begin{array}{c}\text { Corporate } \\
\text { Governance }\end{array}$} & $\begin{array}{l}\text { Between Groups } \\
\text { Within Groups }\end{array}$ & $\begin{array}{c}.302 \\
91.408 \\
\end{array}$ & $\begin{array}{c}2 \\
297 \\
\end{array}$ & $\begin{array}{l}.151 \\
.308 \\
\end{array}$ & .490 & .613 & \\
\hline & Total & 91.709 & 299 & & & & \\
\hline
\end{tabular}

$* \mathrm{~S} \longrightarrow$ Difference is significant across the sectors 
From the Table 5, it is observed that the differences are significant for leadership factors of career and growth opportunities, leader's sensitivity to competitor's HR practices and performance recognition and rewards while the differences are not significant for factors of value \& belief system of the leaders and corporate governance, across IT, services and manufacturing sectors.

Table 6 and Figure 2 reveal that 70 percent of the executives in the manufacturing sector, agree with the practice of shadow resourcing in their respective firms, followed by the IT sector at 67 percent and service sector at 66 percent.

Table 7 and Figure 3 reveals that majority of the firms are in the practice shadow resourcing, for more than a year and is more prevalent in the manufacturing sector as 86.5 percent of the managerial executives ascertaining its practice, followed by the IT sector at 78 percent and services sector at 73 percent.

Table 8 and Figure 4 reveal that 60 percent of the executives from the IT sector agree with the practice of professional hibernation in their respective firms, followed by the services sector at 30 percent and manufacturing sector at 25 percent.

Table 9 and Figure 5 reveal that the percentage of top ranking executives mostly proceeding on professional hibernation is less than five percent and is prevalent in the IT sector with 73.4 percent of the executives ascertaining it, followed by the services at 50 percent and manufacturing at 33.4 percent.

Table 10 and Figure 6 reveal that most of the executives agree with the practice of reverse mentoring. It is more predominant in the manufacturing sector with 67 percent of the executives agreeing with its practice, followed by the IT sector at 56 percent and services sector at 29 percent.

\section{Discussion}

Business leaders should appreciate the fact that the stronger the brand gets in a particular category, the weaker it gets in others and it is also a fact that businesses cannot win on price since there is always somebody who finds a way to make it cheaper! It's ok with delayed cash flows but focus more on growing market and once businesses get enough top line, a lot of obstructions can be fixed. In a corporate environment when people with good ideas have to fight people with good businesses for resources they usually lose out. Over a period of time, better processes and professional commitment make a big difference. If the organizational culture doesn't fit your strategy it is akin to opening a Pandora's Box. Excellent businesses across the world have a Heart Beat!

It isn't the incompetent who destroy an organization. The incompetent never get in a position to destroy it. It is those who have achieved something and want to rest on their laurels clog things up!

Findings show that $90 \%$ of the businesses have failed in their original plans, for their plans are based on too many assumptions.

Business needs leaders who do not try to anticipate the future so much as create it.

Traditionally, in countries across the world, in any sphere of activity, be it economic or philanthropic, people have always tended to follow in the footsteps of a "leader'. In the political field too this is conspicuous in countries like North Korea, China, Vietnam and even India although within India itself, the loyalty towards the leader varies in degrees across the country's vast expanse. If one considers Indian industry, one will realize that most of the budding entrepreneurs of the day would rather regard a Dhirubhai Amnbani or a Narayanamurthy (mentor of Infosys) as their role models; only a few of them would see the 150 year old industrial house of the Tatas as their role model.

What accounts for the higher level of popularity of the Reliance business or Infosys none of which has been around for more than, say 45 years, as compared to the Tatas which has been around for 150 years? The Ambanis were amongst the few Indian industrialists who firmly believed in scale economies. They went in for backward integration at a time when it was considered passé at least in the Indian context. They went for mass production against the backdrop of the global market during pre-liberalization phase! Today, some of their facilities are ranked amongst the top three or five in the world in terms of production and productivity.

Similarly, Infosys spotted opportunities much earlier than others that the information technology sector presented to a country like India on a platter. India's corporate sector and people in general are comfortable in English. The medium of instruction is English at institutions of higher learning in India which made it easier for our graduates to pursue higher education in countries like USA. Additionally, although educational institutions of the mediocre and substandard kind have proliferated all over the country, there are a few of them which are simply world class. Infosys realized soon enough that if the graduates emerging out of the hallowed portals of such world class educational institutions of India are adequately rewarded, cost advantage of the highest level could be achieved in the knowledge-based IT industry. IT industry being a knowledge-based industry, Infosys realized that if it were the early bird, it could, in one full swoop, grab as much business as it wants from the global market. That is what it did and the rest, as they say, is history!

"India Inc's corporate leaders are as motley as they comefrom aggressive Vijay Mallya, to the soft-spoken Narayana Murthy; from the disciplined Azim Premji to the visionary Ratan Tata" ${ }^{,[1]}$. But one thing they have in common is that they are world-beating leaders whose reputations outweigh their personality. Their commitment and focus are bywords in the world of business and their zeal, enterprise and firm sense of ethics sets them apart from the pack. More importantly, they symbolize the new and improved Indian corporate leader, ever ready to break out of the mould. As Indians, these leaders also possess qualities that are unique only to them. This is corroborated by a Hay Group / CEO Magazine study entitled "Confronting the Leadership Crisis" 
that enlists Indian leaders' strengths and weaknesses. The study also points out specific areas that require improvement. So where do Indian leaders stand vis-à-vis their global counterparts? Business executives try and answer this question in the context of India's new business climate.

During the first four decades of independence, India's annual economic growth was sluggish at about 3.5 percent. The focus for business executives then was on consolidation of resources. At the same time, the government's top priorities were to protect and nurture indigenous industries to help them grow. But when the floodgates were flung wide open post-liberalization, leaders found themselves confronted by several competitive challenges. In recent times, with employable talent becoming scarce, hiring and retention have assumed prime importance in the priority list of business leaders. Not only that, new management mantras have evolved and the focus has shifted towards innovation, communication and risk-taking. The Indian environment today is highly competitive and the constantly increasing global pressure of optimization puts leaders through constraints which are new and did not exist in old economy. "Leaders today have to deal with the increasing factors of the new economy and at the same time manage growth", says Rajesh Chandiramani, General Manager, Sales \& Marketing, Tech Mahindra".

The Hay group study says that Indian leaders seem to excel in the entrepreneurial drive, adaptive thinking and networking, while they need to strengthen their understanding or organizational politics, exert influence in complex and sophisticated ways' and assess individual aptitude and strengths and leverage them for business benefits.

Tharuma Rajah, GM, Asia Pacific and Thought Leader Leadership Consulting - Hay Group, believes that leaders in Indian corporation tend to be more obsessed with "business results". "Having almost grown and developed themselves without any internal or external assistance, these leaders do not know how to go about developing other people" says Rajah.

"Leaders here have to face challenges like changing aspirations of employees as an impact of globalization and spiraling costs of talent and growing expectations" comments Girish Wardadkar, President and Executive Director, KPIT Cummins Infosystems Ltd.

Nikhil Maini, Head, Employee Development, 3 Global Services, believes that sailing through change is the biggest challenge Indian leaders come across today. "One cannot 'manage' change as it is a paradox of sorts. To stay ahead in the game, you either 'anticipate the change' or you create the necessary change in your business environment".

"Super bosses begin by seeking out unusually gifted people who are capable of rewriting the definition of success". [2]

Talent acquisition and retention too is something that is a constant worry for Indian leaders. Indeed, going by the mood at industry conclaves and meetings, there is nothing more important than dealing with the talent crunch as far as senior managers are concerned.
Ramesh Vaswani, President, Intex Technologies, feels that finding and retaining the right people and organizing funds for growth at competitive rates (in the case of small scale enterprises and first generation entrepreneurs) are what leaders need to get better at.

Typically, family-owned entitles and PSUs are said to be weaker in terms of the quality of their leadership. However, almost all industry experts tend to believe that no matter what kind of organization you talk about, the only differentiator is the initiative shown by leaders. "The environment for growth in an organization is defined by the attitude of the Managing Director / CEO / Owner," says Vaswani.

"Indian leaders maintain a single-minded focus on innovation, growth, people and business results, as we voraciously seek out new technologies and ideas to adapt to customer's unique needs and opportunities", says Chandiramani, adding, "Further shouldering the needs of corporate social responsibility and taking business risks to address society's needs are some qualities where Indian leads display a more altruistic business philosophy".

Most senior managers are also comfortable working with a multi-cultural workforce. Prashanth L J, Global Chief Marketing Officer, Infinite Computer Solutions says, "The Indian leadership talent with strengths in social values, analytical abilities and balancing diverse cultural requirements is well poised to take on the challenges of global businesses. This makes them competent to multi-task, manage risks holistically, proactively innovative and mange cross-cultural workforce.

So how can India Leaders learn and unlearn new skills to make them more relevant? Is it an excruciating task for Indian companies?

Specialized leadership institutes have a key role to play in accelerating the change in the mindset of old-fashioned leaders and grooming new leaders, Vaswani feels. Organizations like Satyam and Infosys have set up their own leadership training institutes to build and strengthen the quality of leadership internally.

All too often, leaders do not realize the importance of being directly involved in employee affairs. This is a challenge faced by leaders everywhere and not just in India. However, Indian leaders have begun to tackle it in varying degrees. They are beginning to identify employees as their biggest stakeholders. Besides, top-down systems are beginning to make way for collaborative cultures where the CEO works with management teams instead of doing everything on his or her own. But are the effects of globalization and competition accelerating the rate at which our leaders are transforming? Yes and no!

Mere financial success is not a sure-fire indicator of a great leadership at the helm. In addition, leadership is as much an individual quality as an organizational one. This makes it much harder to distinguish between a good leader and a bad one. This makes it much harder to distinguish between a good leader and a bad one. The best leaders, irrespective of where they are, know that greatness comes 
from sharing power instead of hoarding it. Great leaders don't just lead by example they know when and where to delegate. The best leaders concentrate on honing their strengths and find others who can make up for their limitations. As Maini says facetiously, sometimes leadership is about showing the vision and getting the hell out of the way!

The discussion begins with, inter alia, what Mr. Kumar Mangalam Birla, Chairman of the Aditya Birla Group has commented on leadership challenges.

Businesses today are being buffeted by major gale force winds - globalization, liberalization and technology among them. The end result is constant churn, competition and change. In such a hostile environment, incremental change will not suffice; organizations have to radically transform themselves, not once or twice but continuously and many times over. At the broadest level, the topmost task is that of positioning an organization along a permanent transformational track. As Alvin Toffler said, "The illiterates of the $21^{\text {st }}$ Century will not be those who cannot read and write, but those who cannot learn, unlearn and relearn" ${ }^{,[3]}$. Let us now enumerate what we believe is the key challenge facing organizations and leadership today.

Employee engagement is the latest buzzword in HRM. It is the level of commitment and involvement employees have towards their organization and its values. Engaged workers contribute to the firm's increased productivity, higher financial returns, lower attrition, greater talent pool, higher morale and create emotional engagement and loyal customers. Employee Engagement is a critical element of competitive advantage for organizations and is an amalgamation of commitment, loyalty, productivity and ownership. Firms that constantly keep themselves aware of their employees needs with the help of employee satisfaction surveys will have a competitive advantage over those who do not. It is the emotional bond that exists between employer and employee, that makes all the difference.

While ineffective leaders may drag down employee engagement, chasing away some employees while demotivating others, highly effective leaders can create and maintain a work environment marked by loyalty, trust and open communication and inspire employees to give 100 percent. These leaders are successful at driving employee engagement because they possess the following characteristics that define these high engagement leaders.

- Passion to lead

- Select right employees for the right job

- Connect with the employees

\section{- Promote accountability \\ - Develop employee's talent \\ - Recognize the star performer ${ }^{[4]}$}

In a nutshell, only those firms recognize opportunities to foster employee engagement are successful in the long run.

Succession planning is a part of the process of preparing the future plan of the organization. It saves the cost and time of external personnel researches. Every key position and every highly talented person in the organization is a prospect for succession. The firms should identify the strengths of the potential successor and nurture him to fit into the position, which he is aspiring to achieve. To develop and nurture its human capital, firms have to assure a continuing sequence of qualified people to move up and take over, when the current generation of managers and key people retire or move on. Succession planning improves employee morale, lessens the effects of reengineering and downsizing and creates a diverse talent pool within an organization. This will lead the organization way head of its competitors and will help to yield a greater return on investment in future ${ }^{[5]}$.

\section{Leadership}

\section{Identification of Leadership Factors}

Kaiser-Mayer-Olkin (KMO) and Barlett's test of sampling adequacy

The KMO measure of sampling adequacy was used to assess the appropriateness of factor analysis. Table 1 gives the statistics produced by the items of leadership. The KMO values obtained for the leadership variable is 0.787 and this is considered to be adequate to proceed with the factor analysis of the data. This also indicates that there is a high presence of correlation, within the factors of leadership.

Table 2 gives the information with respect to the five identified factors of leadership and their variances. After rotation, it was found that most of the variance is explained by the first factor of leadership and thereafter the remaining four factors, increase only by a small percentage of the variance explained.

Table 3 reveals the factors emerging from the leadership variable along with the factor loadings.

Table 1. Kmo And Barlett'S Test for Leadership

\begin{tabular}{|c|c|c|}
\hline \multicolumn{2}{|c|}{ Kaiser-Meyer-Olkin Measure ofSampling Adequacy } & .787 \\
\hline Barlett's Test of Sphericity & Approx. Chi- Square & 7911.206 \\
\hline & Degree of Freedom (D.F) & 595 \\
\hline & Sig. & .000 \\
\hline
\end{tabular}

Table 2. Representation of Total Variances for Leadership Factors

\begin{tabular}{|c|c|c|c|c|c|c|}
\hline \multirow{2}{*}{ Component } & \multicolumn{3}{|c|}{ Initial Eigen values } & \multicolumn{3}{c|}{ Rotation Sums of Squared Loadings } \\
\cline { 2 - 7 } & Total & \% of Variance & Cumulative \% & Total & \% of Variance & Cumulative \% \\
\hline 1 & 10.741 & 26.852 & 26.852 & 10.741 & 26.852 & 26.852 \\
\hline 2 & 2.652 & 6.629 & 33.481 & 2.652 & 6.629 & 33.481 \\
\hline 3 & 2.409 & 6.022 & 39.504 & 2.409 & 6.022 & 39.504 \\
\hline 4 & 2.057 & 5.141 & 44.645 & 2.057 & 5.141 & 44.645 \\
\hline 5 & 1.974 & 4.935 & 49.580 & 1.974 & 4.935 & 49.580 \\
\hline
\end{tabular}

Extraction Method Principal Component Analysis 
Table 3. Representation of Leadership Factors

\begin{tabular}{|c|c|c|c|c|c|}
\hline Factor 1 : Value and Belief System of the Leaders & 1 & 2 & 3 & 4 & 5 \\
\hline You expect senior leadership to appropriately balance employee interests with those of the organization. & .621 & .304 & & .073 & \\
\hline Your senior management in this organization is open and honest in communication & .758 & .304 & .279 & .389 & \\
\hline Your senior management in this organization provides clear direction for the future & .714 & & & & \\
\hline Your senior management in this organization is appropriately visible \& accessible & .744 & & & & .306 \\
\hline Your senior management in this organization is expert at running the business & .756 & .349 & .167 & & \\
\hline You see strong evidence of effective leadership from the senior management & .620 & .369 & & & \\
\hline Your senior leaders are excellent role models of your organization's values & .506 & .049 & & .151 & \\
\hline Your senior leaders fill you with excitement for the future of the organization & .759 & .100 & & .110 & \\
\hline You have a thorough understanding of the organization's goals \& objectives & .737 & .165 & & .073 & \\
\hline You have confidence in your organization's senior leadership & .385 & .124 & & .081 & \\
\hline You have enough access to the company's business results \& performance & .318 & .253 & .318 & .221 & \\
\hline \multicolumn{6}{|l|}{ Factor 2 : Career Guidance \& Growth Opportunities } \\
\hline Your future opportunities in the organization appear good \& prosperous & .160 & .550 & .240 & .217 & .100 \\
\hline You have appropriate opportunities for personal \& professional growth & .135 & .604 & .067 & & .231 \\
\hline Your manager provides important guidance on career opportunities & .191 & .697 & & & .174 \\
\hline $\begin{array}{l}\text { There are sufficient opportunities within this company for you to develop the skills necessary to assume } \\
\text { greater responsibilities }\end{array}$ & .036 & 610 & & & .005 \\
\hline You have sufficient opportunities to develop the skills necessary for a changing workplace \& world & .153 & .469 & .274 & .074 & .222 \\
\hline Career opportunities here always go to the most qualified people & & .470 & & & .095 \\
\hline This company provides training to help you build skills that are valuable to you & & .520 & & & .018 \\
\hline \multicolumn{6}{|l|}{ Factor $3:$ Leader's Sensitivity to competitor's HR practices } \\
\hline $\begin{array}{l}\text { Your organization is agile relative to other organizations for which you might work, with respect or HR } \\
\text { practices }\end{array}$ & & .126 & .788 & .010 & .293 \\
\hline $\begin{array}{l}\text { Your organization is decisive relative to other organizations for which you might work, with respect or HR } \\
\text { practices }\end{array}$ & & .011 & .562 & .076 & .341 \\
\hline $\begin{array}{l}\text { Your organization is innovative relative to other organizations for which you might work, with respect or } \\
\text { HR practices }\end{array}$ & & .125 & .651 & .149 & .146 \\
\hline $\begin{array}{l}\text { Your organization is team oriented relative to other organizations for which you might work, with respect } \\
\text { or HR practices }\end{array}$ & & & .461 & .240 & .224 \\
\hline $\begin{array}{l}\text { Your organization is result focused relative to other organizations for which you might work, with respect } \\
\text { or HR practices }\end{array}$ & .056 & .216 & .562 & .246 & .103 \\
\hline $\begin{array}{l}\text { Your organization is ethical relative to other organizations for which you might work, with respect or HR } \\
\text { practices }\end{array}$ & .001 & & .619 & & .215 \\
\hline $\begin{array}{l}\text { Your organization is bureaucratic relative to other organizations for which you might work, with respect } \\
\text { or HR practices }\end{array}$ & .296 & .197 & .481 & .111 & .338 \\
\hline Factor $4:$ Performance Recognitions \& Awards & & & . & & \\
\hline $\begin{array}{l}\text { Your performance review process helps in focusing your work efforts to help the company achieve its } \\
\text { goals }\end{array}$ & & .121 & .244 & .714 & \\
\hline The way your company rewards $\&$ recognized people here, helps the firm produce its business results & & & .416 & .744 & \\
\hline Your performance has a significant impact on your pay and perquisites & & & .083 & .756 & .309 \\
\hline You have had a performance review discussion with your manager in the last six months & & & .288 & .620 & .524 \\
\hline $\begin{array}{l}\text { You have had discussion with your manager in the last twelve months about your future career } \\
\text { opportunities with this company }\end{array}$ & & .060 & .007 & .485 & .301 \\
\hline Your firm's reward systems are seen as fair \& equitable & & .194 & .060 & .508 & .199 \\
\hline Your firm frequently looks for excuses to get people together \& celebrate & & & .190 & .705 & \\
\hline Your firm focuses on doing only a few things extremely well & & .236 & .278 & .246 & \\
\hline \multicolumn{6}{|l|}{ Factor $5:$ Corporate Governance } \\
\hline Your firm takes keen interest to address society's needs along corporate social responsibilities dimension & & .199 & & .320 & .387 \\
\hline Your company aligns all actions \& messages with the organization's vision \& core values that ir lives by & & .060 & .213 & & .541 \\
\hline
\end{tabular}

Extraction Method: Principal Component Analysis

Rotation Method: Varimax with Kaiser Normalization 


\section{Analysis of Leadership Factors across the Sectors}

The analysis of the five leadership factors, using mean scores across the sectors of IT, services and manufacturing is represented in the Table 4 and Figure 1

Table 4. Mean Scores of Leadership Factors across the Sectors

\begin{tabular}{|c|c|c|c|c|c|}
\hline Sector & $\begin{array}{c}\text { Value and } \\
\text { Belief } \\
\text { System of } \\
\text { the } \\
\text { Lea ders }\end{array}$ & $\begin{array}{c}\text { Career } \\
\text { Guidance \& } \\
\text { Growth } \\
\text { Opportunities }\end{array}$ & $\begin{array}{c}\text { Leader's } \\
\text { Sensitivity to } \\
\text { Competitors } \\
\text { HR Practices }\end{array}$ & $\begin{array}{c}\text { Performance } \\
\text { Recognition } \\
\text { and Rewar ds }\end{array}$ & $\begin{array}{c}\text { Corporate } \\
\text { Governance }\end{array}$ \\
& (A) & (B) & (C) & (D) \\
\hline IT & 3.8764 & 3.7443 & 3.7929 & 3.7175 & 3.7250 \\
\hline Services & 3.9264 & 3.9614 & 3.8014 & 3.8488 & 3.9300 \\
\hline Manufacturing & 3.5745 & 3.5714 & 3.6157 & 3.5400 & 3.4800 \\
\hline
\end{tabular}

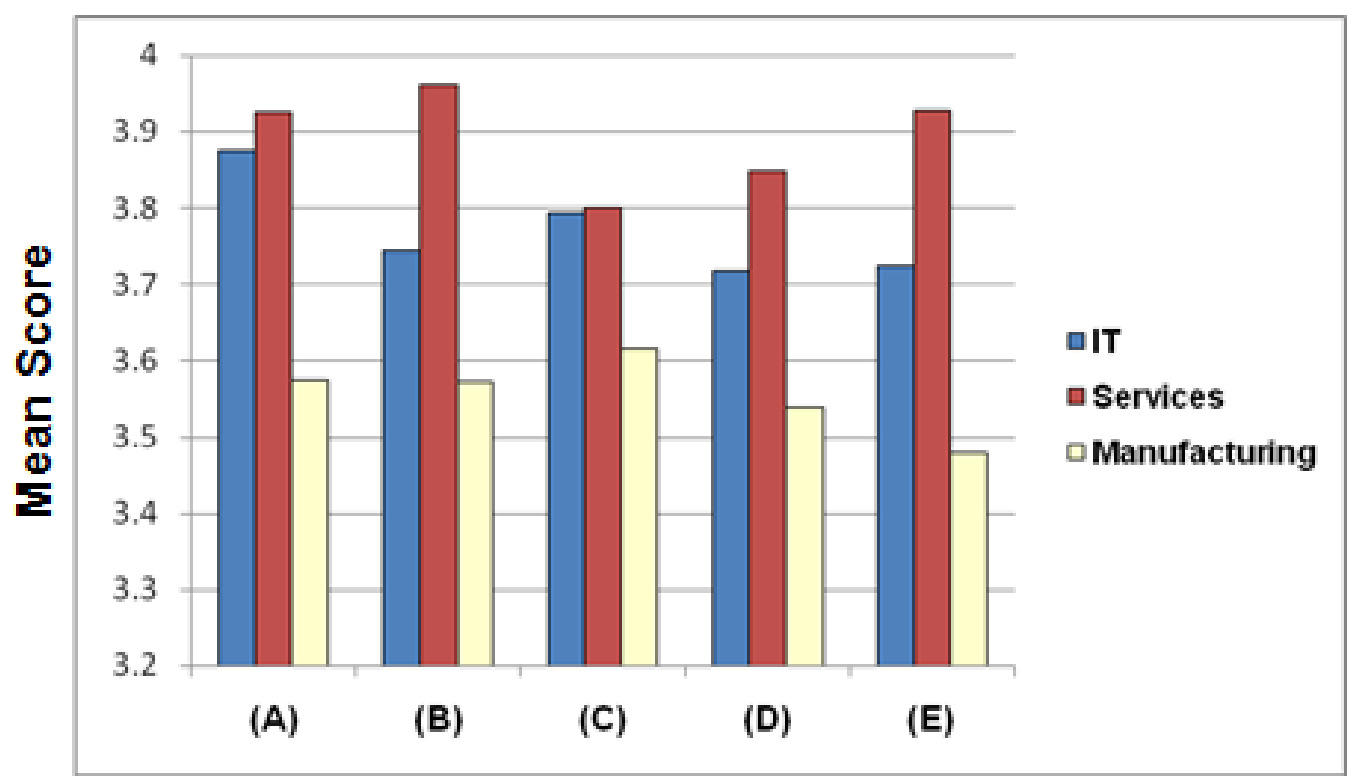

Figure 1. Mean Scores of Leadership Factors across the Sectors

\section{Related Issues of Leadership}

Few novel HR practices with respect to leadership, which could not be subjected to factor analysis have been analyzed separately as follows

Shadow Resourcing or Succession Planning

The degree to which the managerial executives of IT, services and manufacturing sector perceive the practice of shadow resourcing varies on a scale of strongly disagree to strongly agree, as shown in the Table 6 and Figure 2 
Table 6. Practice of Shadow Resourcing

\begin{tabular}{|c|c|c|c|c|c|c|}
\hline Sector & $\begin{array}{c}\text { Strongly } \\
\text { Disagee }\end{array}$ & Disagree & Neutral & Agree & $\begin{array}{c}\text { Strongly } \\
\text { Agree }\end{array}$ & Total \\
\hline IT & 0 & 2 & 25 & 67 & 6 & 100 \\
\hline Services & 0 & 6 & 20 & 66 & 8 & 100 \\
\hline Manufacturing & 0 & 6 & 20 & 70 & 4 & 100 \\
\hline Total & 0 & 14 & 65 & 203 & 18 & 300 \\
\hline
\end{tabular}

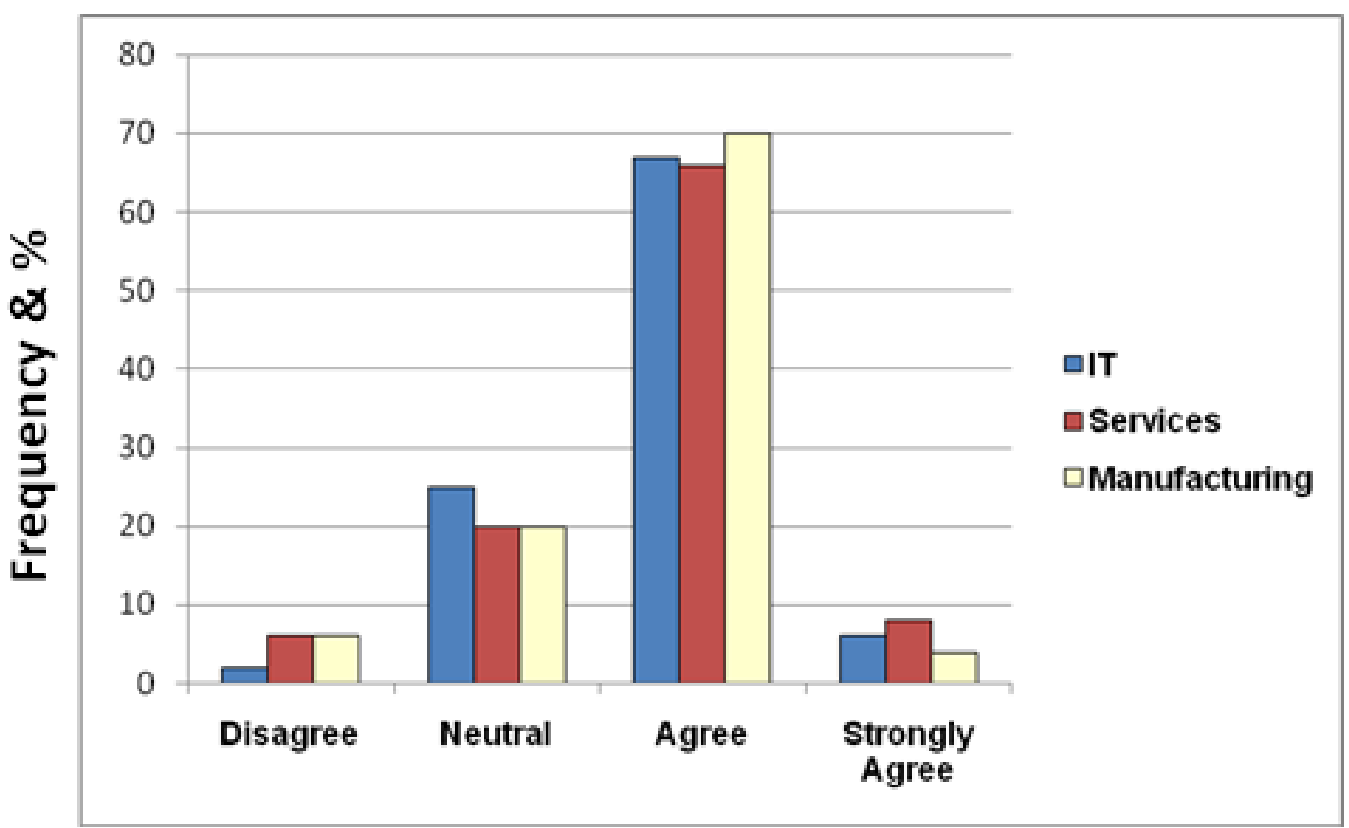

Figure 2.Practice of Shadow Resourcing

\section{Time Period of the Practice of Shadow Resourcing/Succession Planning}

The executives who agreed or strongly agreed for the practice of shadow resourcing in their respective firms, were further queried to specify the time period of its practice and the results are shown in the Table 7 and Figure 3

Table 7. Time Period Of The Practice Of Shadow Resourcing

\begin{tabular}{|c|c|c|c|c|c|c|c|}
\hline \multirow{2}{*}{ Sector } & \multicolumn{2}{|c|}{$\begin{array}{c}\text { Less than } \\
\text { Six Months }\end{array}$} & \multicolumn{2}{c|}{$\begin{array}{c}\text { Six Months } \\
\text { to } \\
\text { One Year }\end{array}$} & \multicolumn{2}{c|}{$\begin{array}{c}\text { More than } \\
\text { a } \\
\text { Year }\end{array}$} & \multirow{2}{*}{ Total } \\
\cline { 2 - 8 } & Score & $\%$ & Score & $\%$ & Score & $\%$ & \\
\hline IT & 4 & 5.4 & 12 & 16.4 & 57 & 78 & 73 \\
\hline Services & 16 & 21.6 & 4 & 5.4 & 54 & 73 & 74 \\
\hline Manufacturing & 0 & 0 & 10 & 13.5 & 64 & 86.5 & 74 \\
\hline TOTAL & 20 & & 26 & & 175 & & 221 \\
\hline
\end{tabular}




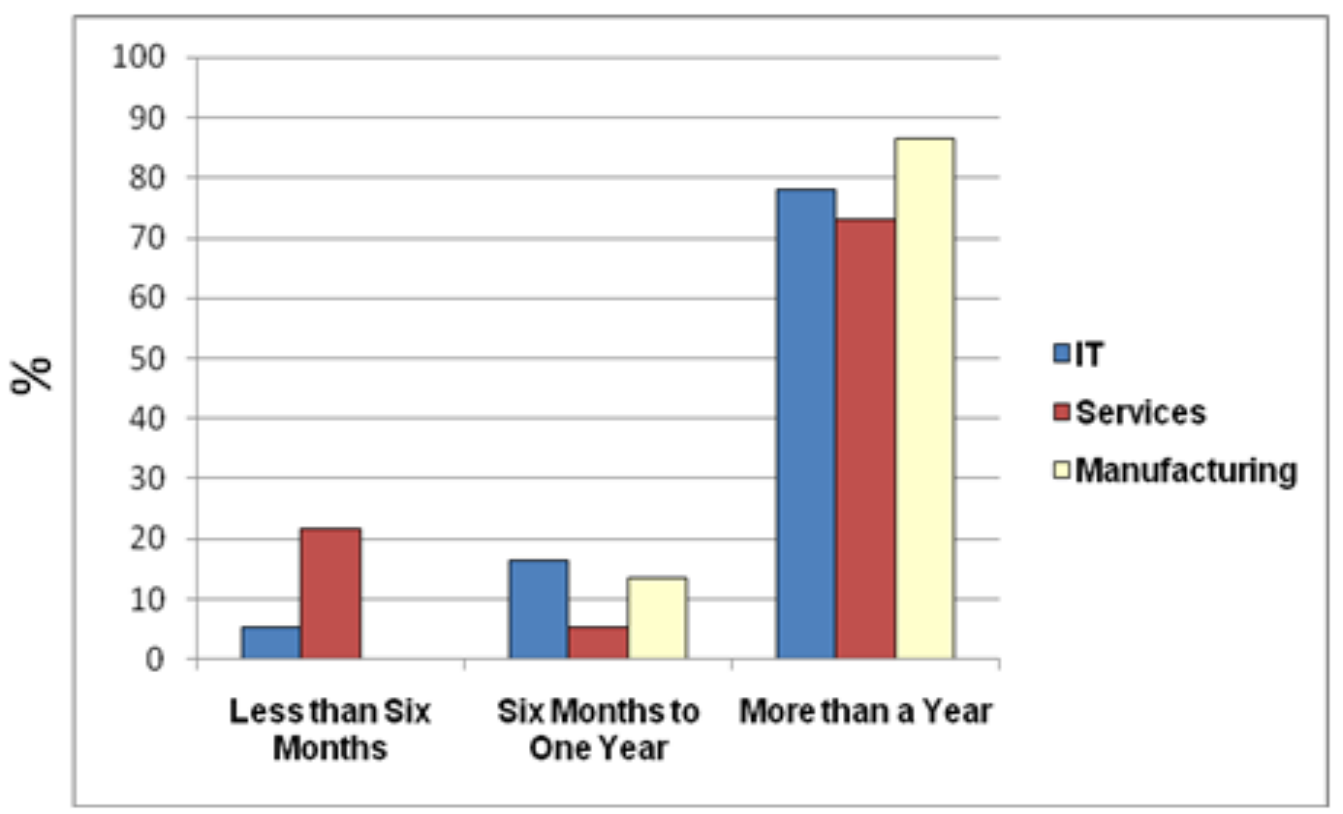

Figure 3. Time Period of the Practice of Shadow Resourcing/Successive Planning

\section{Professional Hibernation}

The degree to which the executives of IT, services and manufacturing perceive the practice of professional hibernation in their workplaces, varies on a scale of strong disagree to strongly agree, as shown in the Table 8 and Figure 4

Table 8. Practice of Professional Hibernation

\begin{tabular}{|c|c|c|c|c|c|c|}
\hline Sector & $\begin{array}{c}\text { Strongly } \\
\text { Disagree }\end{array}$ & Disagree & Neutral & Agree & $\begin{array}{c}\text { Strongly } \\
\text { Agree }\end{array}$ & Total \\
\hline IT & 0 & 17 & 19 & 60 & 4 & 100 \\
\hline Services & 8 & 28 & 22 & 30 & 12 & 100 \\
\hline Manufacturing & 0 & 62 & 8 & 25 & 5 & 100 \\
\hline Total & 8 & 107 & 49 & 115 & 21 & 300 \\
\hline
\end{tabular}

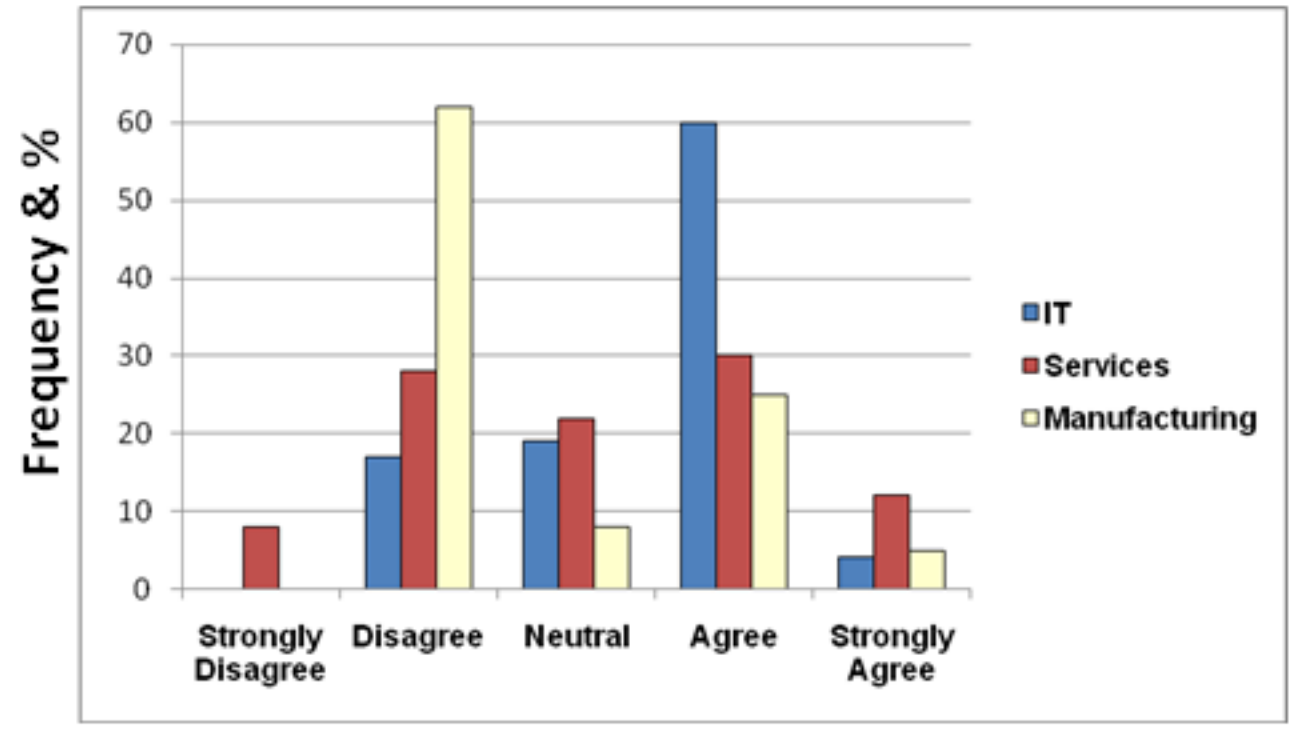

Figure 4. Practice of Professional Hibernation 


\section{Extent of Practice of Professional Hibernation}

The executives who agreed and strongly agreed for the practice of professional hibernation in their respective firms, were further queried to specify the percentage of top ranking executives proceeding on professional hibernation and the results are shown in table 9 and Figure 5.

Table 9. Extent of Practice of Professional Hibernation

\begin{tabular}{|c|l|l|l|l|l|c|c|c|c|}
\hline \multirow{2}{*}{ Sector } & \multicolumn{2}{|c|}{$<5 \%$} & \multicolumn{2}{|c|}{$5 \%$ to $10 \%$} & \multicolumn{2}{|c|}{$10 \%$ to $20 \%$} & \multicolumn{2}{|c|}{$>20 \%$} & \multirow{2}{*}{ Total } \\
\cline { 2 - 9 } & Score & $\%$ & Score & $\%$ & Score & $\%$ & Score & $\%$ & \\
\hline IT & 47 & 73.4 & 10 & 15.6 & 2 & 3.1 & 5 & 7.9 & 64 \\
\hline Services & 21 & 50 & 14 & 33.33 & 4 & 9.5 & 3 & 7.2 & 42 \\
\hline Manufacturing & 10 & 33.4 & 12 & 40 & 4 & 13.3 & 4 & 13.3 & 30 \\
\hline TOTAL & 78 & & 36 & & 10 & & 12 & & 136 \\
\hline
\end{tabular}

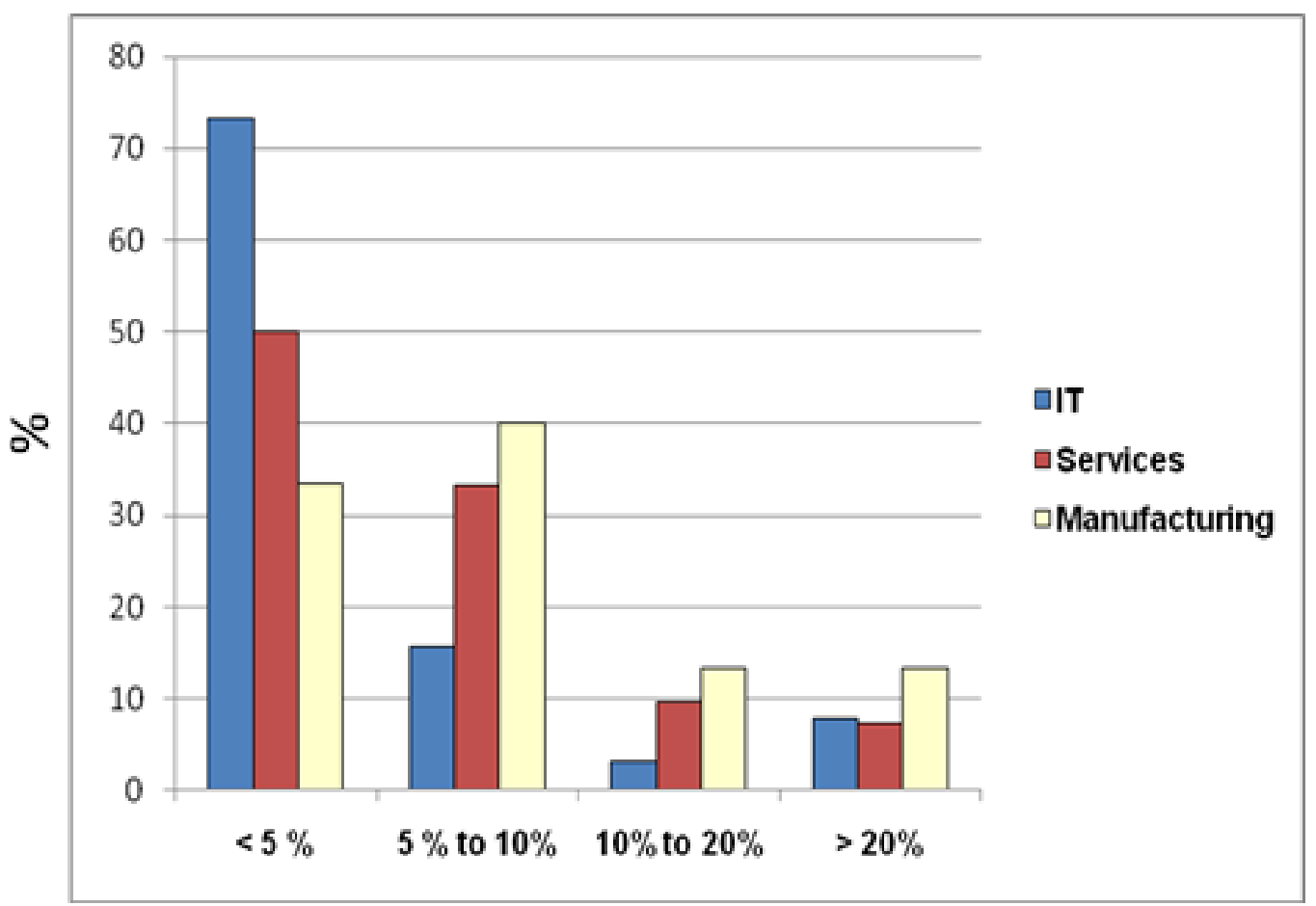

Figure 5. Extent of Practice of Professional Hibernation

\section{Reverse Mentoring}

The degree to which the executives perceive the practice of reverse mentoring in their respective firms, varies on a scale of strongly disagree to strongly agree as shown in Table 10 and Figure 6. 
Table 10. Practice of Reverse Mentoring

\begin{tabular}{|c|c|c|c|c|c|c|}
\hline Sector & $\begin{array}{c}\text { Strongly } \\
\text { Disagree } \\
(\mathrm{A})\end{array}$ & $\begin{array}{c}\text { Disagee } \\
(\mathrm{B})\end{array}$ & $\begin{array}{c}\text { Neutral } \\
(\mathrm{C})\end{array}$ & $\begin{array}{c}\text { Agree } \\
\text { (D) }\end{array}$ & $\begin{array}{c}\text { Strongly } \\
\text { Agree } \\
\text { (E) }\end{array}$ & Total \\
\hline IT & 15 & 9 & 14 & 56 & 6 & 100 \\
\hline Services & 8 & 29 & 20 & 29 & 14 & 100 \\
\hline Manufacturing & 10 & 14 & 9 & 67 & 0 & 100 \\
\hline Total & 33 & 52 & 43 & 152 & 20 & 300 \\
\hline
\end{tabular}

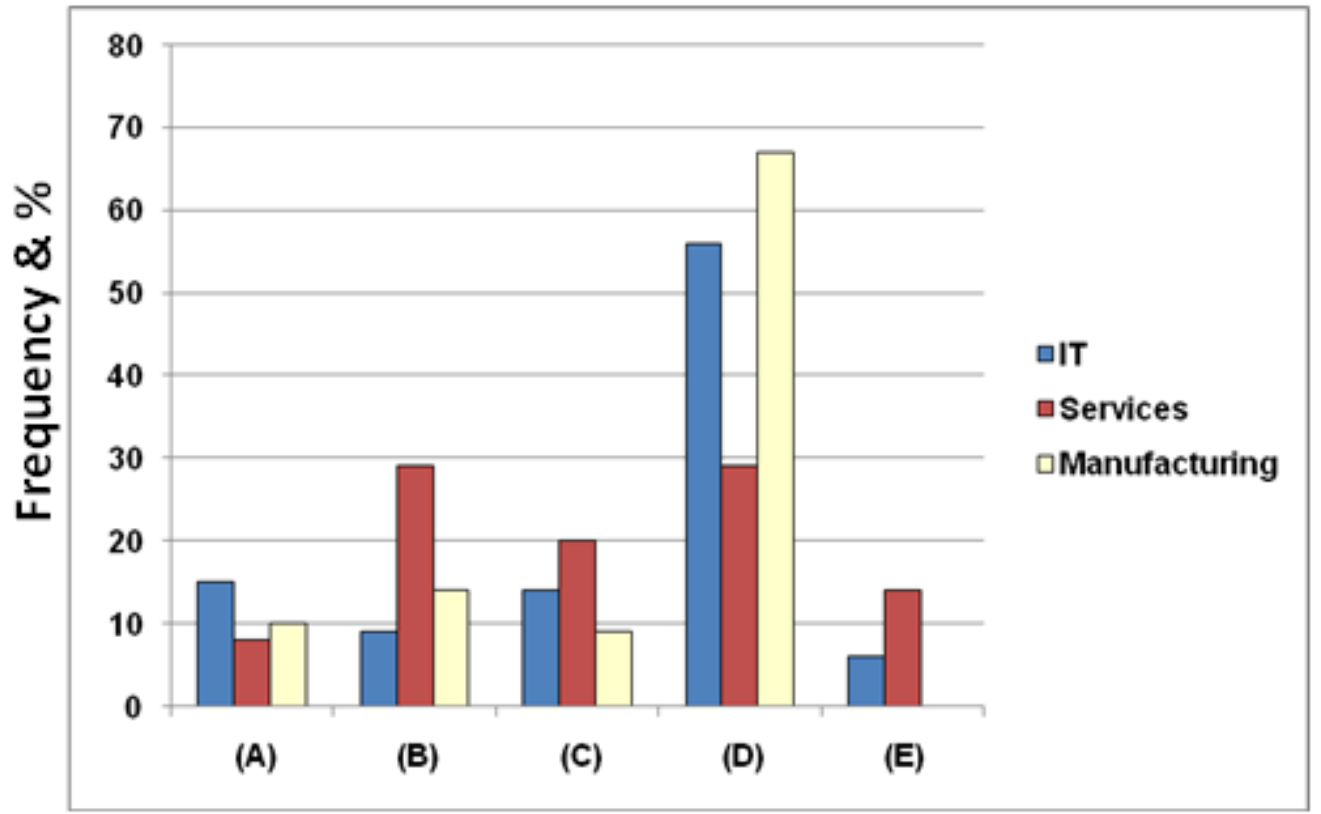

Figure 6. Practice of Reverse Mentoring

\section{Summary of Findings \& Conclusion}

Summary of Findings

\begin{tabular}{|c|c|c|c|c|}
\hline $\begin{array}{c}\text { Sl. } \\
\text { No. }\end{array}$ & HR Practices & Leader Firms & Follower Firms & Laggards \\
\hline a. & $\begin{array}{c}\text { LEADERSHIP } \\
\text { Value and belief system of the leaders }\end{array}$ & $\begin{array}{c}\text { IT, Services \& } \\
\text { Manufacturing }\end{array}$ & -- & - \\
\hline b. & $\begin{array}{c}\text { Career guidance and growth } \\
\text { opportunities }\end{array}$ & Services & IT and Manufacturing & - \\
\hline c. & $\begin{array}{c}\text { Leader's sensitivity to competitor's } \\
\text { HR practices }\end{array}$ & Services & IT and Manufacturing & -- \\
\hline d. & $\begin{array}{c}\text { Performance recognition and reward } \\
\text { system }\end{array}$ & Services & IT and Manufacturing & -- \\
\hline e. & Corporate governance & $\begin{array}{c}\text { IT, Services \& } \\
\text { Manufacturing }\end{array}$ & -- & - \\
\hline f. & $\begin{array}{c}\text { Shadow resourcing or } \\
\text { Succession Planning }\end{array}$ & Manufacturing & IT and Services & - \\
\hline g. & Professional Hibernation & IT & Services \& Manufacturing & \\
\hline
\end{tabular}


Thus leadership is ultimately to do with people. You can have the most forward-looking vision and strategy, but unless you have a passionate and committed team to execute it, you cannot translate your vision into reality. It is important to muster the emotional and intellectual equity of the people and to gain their trust and commitment to the vision. Leadership is all about rallying them around to a compelling and exciting vision of the future. It is about plucking into the minds and hearts of people. It is about upping the quality of imagination of the organization. It is about encouraging a spirit of intellectual ferment and constructive dissent so that people are not bound by the status quo and star performers are given space and free play. It is about building the highest levels of empathy, without compromising on fairness and running a popularity contest.

Thus, the process of change is perhaps 90 percent about leadership and only 10 percent about managing.

\section{REFERENCES}

[1] The Economic Times, June 20, 2006.

[2] Sydney, "Managing Yourself", Harward Business Review, South Asia, January - February 2016.

[3] Kumar Mangalam Birla, Chairman, Aditya Birla Group in "Leadership challenges in an Era of Globalization", Business Today, January 16, 2005.

[4] Rich Wellins and Jim Concelman, "Creating a Culture for Engagement", www.smag.com.

[5] V. V Ramani, Succession Plan, Hyderabad ICFAI University Press, 2005.
[6] Armstrong \& Baron, Performance Management : The New Realities, Institute of Personnel \& Development, 1998.

[7] Bateman, "Management Competing In The New Era", New Delhi, Tata Mc. Graw Hill, 2006.

[8] Esther Cameron \& Mike Green, Making Sense of Change Management, UK, Kogan page India, 2004.

[9] Jena McGregor and Steve Hamm, "Managing the Workforce", Business Week, January 28, 2008.

[10] Pallavi \& Arvind Kumar Mishra, "Innovative HR Practices by Organizations”, HRM Review, May 2010.

[11] John Baldoni, "HR Factored", The Human Factor, Feb 2012.

[12] Alokesh Bhattacharya, "Counsel for the Wise", Business Today, Sep 16, 2012.

[13] Dori Meinert, "Organizational \& Employee Development", HR Magazine, August 2014.

[14] Dori Meinert, "25 Fun \& Easy Ways to Boost Morale", $H R$ Magazine, July/Aug 2015.

[15] Nitin Pangarkar, High Performance Companies, Jossey-Bass, 2012.

[16] Harsh Dwivedi \& Smita Choudharay, "Leadership Styles of Managers of Top Three IT Companies", Indian Journal of Training \& Development, Vol XXXX1-No.2 - Apr-June 2011.

[17] Germano Glufki Reis, Maria Jose Tonelli and Maria Tereza Fluery, "HRM in Brazalian Multinational", Journal of Management \& Entrepreneurship, July-Sep 2012.

[18] /Christopher Baond, "HR Practices in the UK : A Review and Evaluation of Contemporary Approaches to HRM", Journal of Management \& Entrepreneurship, July-Sep 2012. 